\title{
特集【論説】不動産のマネジメント 第二部 不動産マネジメントの現状と課題
}

\section{不動産を利用する場面でのマネジメント \\ Management in scene that uses real estate}

Harunori SUZUKI : Manager, Management Planning Department,

Tokyo Electric Power Company Real Estate Ltd.

鈴木 晴紀*

\section{I .はじめに}

本稿では, 不動産を利用する場面でのマネジメ ントとして, ファシリティマネジメント（以下， FMと記す）を採り上げて，まず，その歴史と定 義と目標及び業務を紹介し, 次に, FMの代表的 な手法と実施プロセスを示した上で，FMを規定 する情報の現状と課題, 不動産価格や景気と FM との関係について整理を試みるものである。

\section{II . FMとは}

\section{FMの歴史}

FMは, アメリカで発祥し，その源流は，1960 年代における工場施設の近代化計画と総合的な固 定資産管理（CRE: Corporate Real Estate）に遡 る1）。アメリカでは, 1961年にCREの普及・定着 を推進するIDRC（現在のCore Net-Global）が, 1979年にFMに関する研究機関であるFMIが設立 され，翌年の1980年にFMの普及・定着を推進す るIFMAが設立されている1)。

日本に㧍けるFMに関連する団体は, JFMA (社)日本ファシリティマネジメント推進協会), NOPA（社)ニューオフィス推進協議会), BELCA (社)建築・設備維持保全推進協会) の 3 団体があり, その設立は, JFMAとNOPAが1987年, BELCA
が1989年である。

1997年には，これらの 3 団体で構成されるFM 推進連絡協議会が組織され, 認定ファシリティマ ネジャー資格（CFMJ）制度が創設され，2008年 までの累計で, 応募者は約24,700名, 合格者は約 9,100名, 登録者は約6,420名を数えるに至っている。

\section{FMの定義}

JFMAの定款では，FMは，「企業等が有する全 施設及び当該施設の利用環境を経営戦略的な視点 から総合的に企画，管理，活用する経営管理活動」 と定義している。また, FM推進連絡協議会が編 者である文献 2 では, 「企業・団体等が組織活動の ために，施設とその環境を総合的に企画，管理， 活用する経営活動」と定義している。

換言すれば, FMは，経営資源の「もの」の大 部分を占めるファシリティ（施設（土地・建物・ 備品）とその環境）に着目した経営管理活動であ り，その実践により，「ひと」「かね」及び「情報」

表 $1 ： \mathrm{FM}$ と経営資源の最適化

\begin{tabular}{c|l}
\hline ひと & 知的生産性の向上 \\
もの & 資産の高 度利 活 用 \\
\hline かね & 施設に関する費用の削減 \\
\hline 情報 & 高度情 報化の推 進 \\
\hline
\end{tabular}


を含めた全ての経営資源を最適化するもの（表 1 参照）であると言える。

\section{FMの目標}

FMは, 財務, 供給, 品質の 3 つの目標をバラ ンス良く改善し続ける活動であり, どれか一つに 偏っても，また，どれか一つを疎かにしてもFM の実践としては不適切である。

「財務目標」は, 施設に関する費用（以下，ファ シリティコストという）を最小化するという目標 である。その達成に向けては, 施設を資産として 捉えて, その取得費用のみならず生涯費用にも着 目した取り組みをする必要がある。

また，「供給目標」は，施設に関する需給への対 応性, 即ち, 所有または賃借している施設の規模 を最適化して, なおかつ, 供給されている施設を 最大限に利活用するという目標である。

更に,「品質目標」は, 施設に求められた機能と 品質を最適化して, なおかつ, 施設を利用する者

表 $2 ：$ FM標準業務 ${ }^{2}$

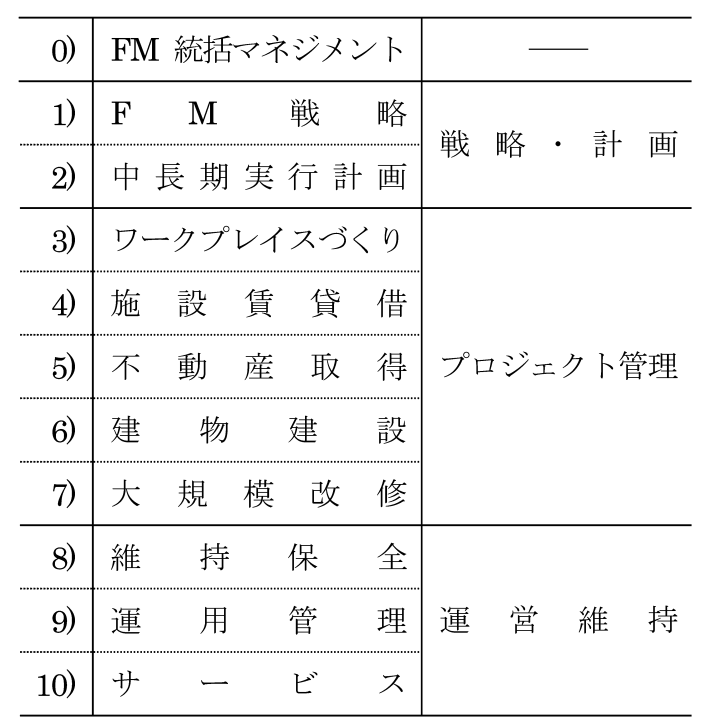

の満足度を向上させるという目標である。具体的 には, 品格性, 快適性, 生産性, 信頼性, 環境保 全性, 満足度の 6 種類の項目で評価される。

\section{FMの業務}

FMの標準業務は, 表 2 の通り, 統括マネジメ ント (Action), FM戦略・計画 (Plan), プロジェ クト管理 (Do), 運営維持 (Do) の 4 つから構成 される。そして, FMは, これに, FMの 3 つの目 標である財務と供給と品質に関する評価 (Check) を加えて，FMサイクル（PDCA）（図１参照）を 廻し続ける活動であると言える。

「統括マネジメント」は, 組織全体の一元的な FM業務を円滑かつ効率的に実施するために, 組 織と体制の策定, 情報の収集と管理, 標準と規程 の策定，財務の管理を行う業務である。

「戦略・計画」の内, 「FM戦略」は, 組織の経 営戦略に基づき, 総合的なファシリティの施策を 策定する業務であり，「中長期実行計画」は，FM

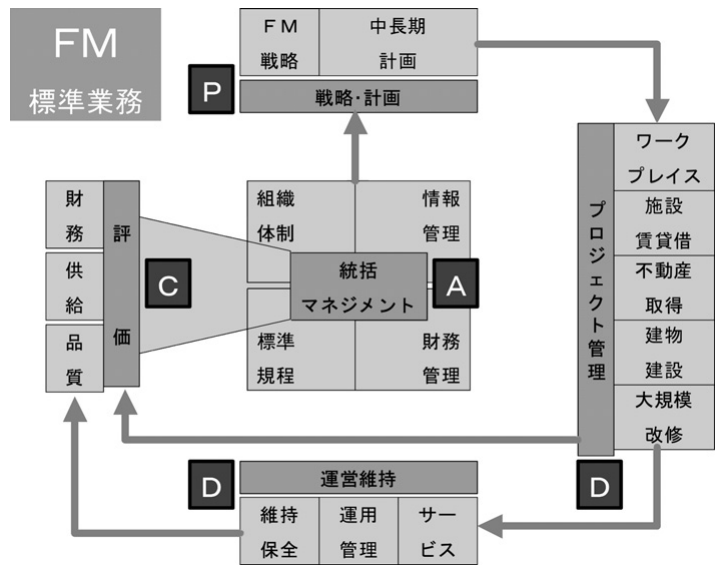

図 1：FMサイクル

\footnotetext{
${ }^{2)}$ FM推進連絡協議会編（2003.01），「総解説ファシリティマネジメント」，日本経済新聞社
} 
戦略に基づき，FMの定量的な目標とその実行計 画を策定する業務である。

「プロジェクト管理」は，一定期間内に完了する プロジェクトを管理する業務であり，施設資産の 取得や縮減に関わる「施設賃貸借」と「不動産取 得」及び「建物建設」, 施設資産の使われ方の変化 に対応する「ワークプレイスづくり」と「大規模 改修」の合計で 5 つの業務がある。

「運営維持」は, 施設資産の適切な状態に保つ業 務である「維持保全」, 施設資産の運用と利用する 者へのサービスを提供する「運用管理」及び「サー ビス」の 3 つの業務がある。

なお, 因みに, 欧米諸国では, 日本における「FM の標準業務」の内, 「.運営維持」に関わるマネジ メントのことを「FM」ということが多い。

\section{FMの代表的な手法と実施プロセス}

\section{1. 評価}

(1) 財務評価

FMの財務目標は, 建物毎に把握したファシリ ティコストで評価される。

ファシリティコストは, 施設の維持, 運用, 管 理に直接または間接に要する費用であり, 維持費 (保有費と保全費) と運営費及び管理費で構成され

\section{る(表 3 参照)。}

これらの内，保有費は，施設の売却や返却する 等, 自らが使用している施設を縮減しない限り削 減できないが，保全費と運営費は，FM標準業務 の「運営維持」業務を通じた削減が可能である。

基本的には, ベンチマーキングの手法等により, 「単位面積当たりのファシリティコスト」と「一人 当たりのファシリティコスト」及び「一人当たり の面積」を評価する。

(2) 供給評価

FMの供給目標は, 建物毎と用途毎に把握した
表 3 : ファシリティコストの内訳 ${ }^{3)}$

\begin{tabular}{|c|c|c|}
\hline 大分類 & 小分類 & 科目 \\
\hline \multirow{3}{*}{ 維持費 } & \multirow{2}{*}{ 保有費 } & 賃借料, 租税公課, 保険料 \\
\hline & & 減価償却費(有形,無形), 資本コスト \\
\hline & 保全費 & $\begin{array}{l}\text { 保守費, 清掃費, 病害虫防除費, 修繕 } \\
\text { 費, 廃棄物処理費, リサイクル費 }\end{array}$ \\
\hline 運 & 費 & $\begin{array}{l}\text { 水道光熱費, ファシリティ運営費, セ } \\
\text { キュリティ費, 業務支援費, 生活支援 } \\
\text { 費, 家具什器費, パーキング費 }\end{array}$ \\
\hline 管 & 費 & 統括管理費 \\
\hline
\end{tabular}

施設の規模と利用度で評価する。

施設の規模は, 例えば, オフィスの場合, 執務 室のように人が常時占有している空間は「一人当 たりの面積」で評価して, 会議室や応接室のよう に必要なときに適宜利用する空間は「利用度」で 評価する。

基本的には，施設を構成する要素ごとに策定し た「面積標準」に基づき, 実地監査を行って評価 するが，後述するベンチマーキングの手法も用い られる。

供給評価の結果に基づき, 適切な時期に, FM 標準業務の「プロジェクト管理」業務を実施して, 各種スペースの規模の適正化, 余㮃スペースの処 分等を行う。

(3) 品質評価

$\mathrm{FM}$ の品質目標は, 定性的にならざるを得ない ためその評価は難しいが, 代表的な評価項目とし ては，例えば，施設の残存不具合率と性能評価指 標及び利用者満足度が挙げられる。

施設の残存不具合率 (FCI : Facility Condition Index）は, 経年劣化による不具合の残存率であり，

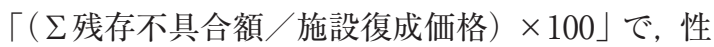

3)(社)日本ファシリティマネジメント推進協会 (2001.01), 「施設に関する費用認識·管理会計基準に係る調査研究報告書」 
能評価指数（PI：Performance Index）は, 陳腐 化の進展度であり,「（（改善改良費／施設復成価 格）×100」で算定される。

利用者満足度は，ファシリティを利用する者が 現状のファシリティにどの程度満足しているかを アンケート調査によって把握するものである。 FM標準業務の「プロジェクト管理」業務の着手 前と完了後に行うと共に, 毎年 1 回度程度, 定期 的に行う。

(4) ベンチマーキング

FMにおけるベンチマーキングとは，他組織が 実践している優良なFM事例に学んで, 自己改革 をするものである。即ち, ベンチマークの対象と なる優良なFM事例を分析して, 各種の目標值を 設定して，自組織のFMを実施するものである。

JFMAでは, ベンチマークセンターを設置して, 定期的に企業及び団体に対して，FMのベンチ マーキングを行うために必要なデー夕を調査して おり, その結果をFMベンチマーク調査報告書と して公開している。主な調查項目は, FM推進の 体制, 標準 - 規定の有無, 所有 - 賃貸の別, 組織 全体の棟数, 棟別の規模 - 用途, 面積と収容人員, ワークプレイスの類型, ファシリティコスト, 利 用者満足度調査の実施状況, 廃裹物の量, エネル ギー使用量等である。

なお, ベンチマークとは, 地盤の高低差を図る 水準測量で用いられる水準点のことである。

\section{2. 統括マネジメント}

(1) 組織・体制

FMは，全ての組織に関わるマネジメントであ るため, トップダウンにより, 全ての施設を一元 的にマネジメントできる体制を構築する必要があ る。具体的なFM推進体制としては, 役員直轄の FM専門組織によるものと, 役員を委員長とする 委員会でFMに関わる意志決定を行うもの等があ る。

\section{（2）標準 /規程・情報管理・財務管理}

FMを推進するために必要な標準/規程の策定, 情報管理と財務管理のための仕組みと体制を構築 する。標準/規程としては, 施設標準, 環境標準, 面積標準, 運営維持標準, 財務標準等があるが, 特に, FMの 3 つの目標（財務・供給・品質）に 深く関わる面積標準が特に重要である。情報管理 と財務管理については, 後述するが, ITの活用が 不可欠である。

\section{3. 戦略・計画}

(1) ポートフォリオの策定

FMの財務評価と供給評価及び品質評価の結果 に基づき, 経営資源であるファシリティを施設資 産と捉えたポートフォリオを策定する。

具体的には, まず, 例えば, 外部価值, 内部価 值, 利用度, 健全度等の評価軸から 2 つを選んで, それぞれの評価軸を数個に区分して 2 次元に表示 した妌に分けて，それぞれの妌毎に施設資産の戦 略を策定する (図 2 参照)。次に, 保有または賃借 している全てのファシリティを各妌に当てはめて, 該当する施設戦略に基づいてFMを実践する。

(2) 総量縮減

施設資産のポートフォリオにより, 現状の施設 群は, 例えば,「現状余剩」,「将来余剩」,「機能劣 化」した施設群,「健全」な施設群の 4 つのグルー

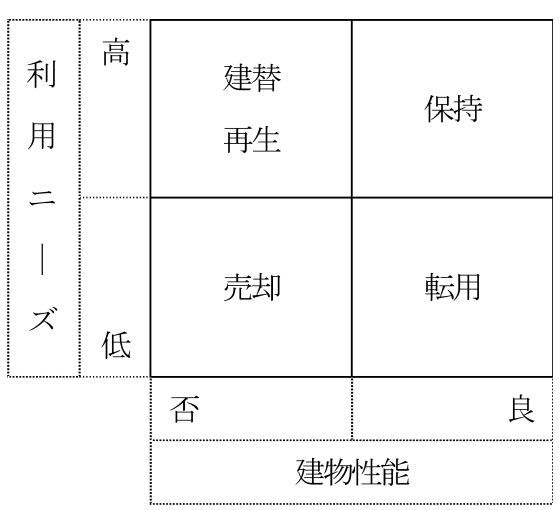

図 2 : ポートフォリオの例 5 ) 


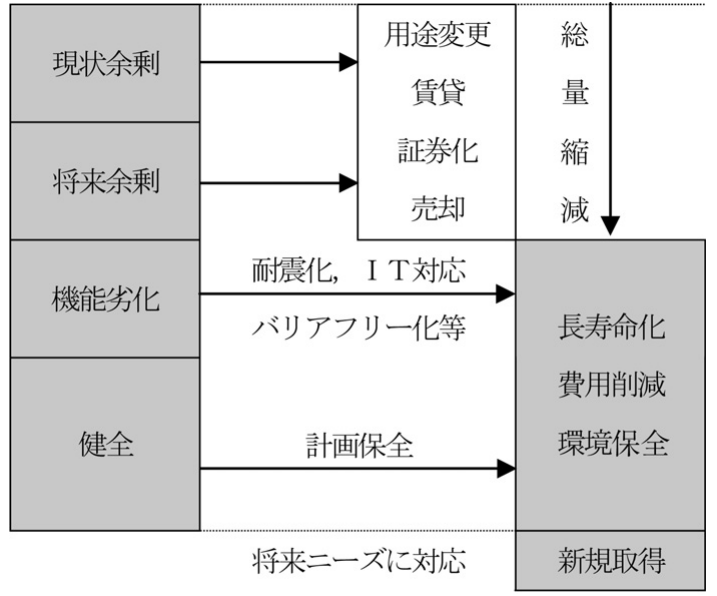

[現状]

[将来]

図 3：施設資産の現状と将来 ${ }^{4)}$

\section{プに分類することができる（図 3 参照）。}

この内,「現状余剩」と「将来余剩」の施設資産 は, 用途変更や賃借や証券化及び売却等を行って, 自らが使用する施設資産の総量を縮減することに なる。その結果, 将来の施設群は, 「機能劣化」し た施設群を耐震化やIT対応及びバリアフリー化 等を行ったもの,「健全」な施設群を計画的な保全 を行ったもの, そして, 将来ニーズに対応して 「新規取得」したものを合わせた施設群となる。こ れらの施設群は, FM標準業務の「運営維持」業 務を通じて，長寿命化と費用削減及び環境保全が 図られることになる。

\section{4.プロジェクト管理}

(1) 統合か分散か

多くの場合, 立地の変更を伴うが, 分散したファ シリティを統合することにより，次のようなメ リットを享受することができる。

(1)安価で大規模な施設を確保できる場合は, ファシリティコストを大幅に削減できる。

(2)ロビー, 受付, 会議室等の分散した施設の間 で重複していたスペースが削減できる。

(3)分散した施設の間を往復する交通費や電話料 等のコミュニケーション費が削減できる。

(4)分散した施設を移動する時間の節約されて, チームワークと業務の効率が向上する。

(5)社員に対する業務や生活等の支援やサービス が効率化できる。

従来から施設の統合は, 多くの組織で行われて きたが，2003年をピークとして大規模なファシリ ティの供給が増加しており, 現在でもより現実的 な施策となっている。

(2) 都心か郊外か

近年, 情報インフラストラクチャの整備が進展 したことにより，地方都市や郊外にも大規模な施 設が供給されていると共に，「いつでもどこでも」 業務ができる環境が整ってきている。

施設の立地は, 次のように様々な要素を考慮し て決定される。

(1)企業イメージやリクルートにも影響を与える。 (2)顧客や取引企業の近くにあるべきである。

(3)社員の通勤に要する時間と費用は日常的な問 題である。

(4)社員の働く場は生活の場でもある。

(5)施設の保有費は膨大である。

施設の移転は, ビジネス環境の変化に応じて, 頻繁に行われているが，特に，施設の保有費が高 額な立地の場合は, 高度なスペース効率と知的生 産性をより一層追及したワークプレイスづくりが 行われている。

(3) 所有か賃借か

自らが利用する施設を「所有」すべきか「賃借」 すべきかという問題は，常に課題となる。

この問題は，不動産の価格とその流動性及びビ

\footnotetext{
4)(社)日本ファシリティマネジメント推進協会（2009.02），「FM財務評価ハンドブック2009」

${ }^{5)} \mathrm{FM}$ 推進連絡協議会編（2009.03），「総解説ファシリティマネジメント一追補版」，日本経済新聞社
} 
ジネス環境の変化等, 将来の予測が難しい要素と 関係しており，その意思決定は経営判断によると ころが大きい。一般的に言及されているそれぞれ の長所と短所は，次の通りである。

(1)ファシリティコストは, 資本コストを考慮す ると「所有」した場合の方が若干安いが,「所 有」と「賃借」で大きな差はない。

(2)「所有」した場合は, 経年劣化や陳腐化によ る資産価值の低下，昇降機や回転扉及び外壁 等, 施設の不具合に起因する公衆災害の際に 問われる所有者責任等のリスクがある。

(3)「賃借」した場合は, 賃貸借契約を更新する 際に賃借料や共益費の交渉が思うように行か ない等のリスクがある。

一般に, ビジネスを取り巻く環境の変化が激し い業界の企業は，「賃借」を志向する傾向がある。 また，自らが「所有」して利用する施設を建設す る際も，自らしか使えない専用仕様を極力避けて， 自らが利用しない余剩なスペースを他の組織に賃 貸できる施設とするのが一般的になっている。

(4) 課金制度

ファシリティコストは，膨大であることから， 次の 2 つを目的として, 課金制度を導入する組織 が増えている。この制度は, 入居部門に対して, 執務室のように常時占有している空間は, その占 有面積に応じて, 共用の会議室や応接室のように 必要な時に適宜利用する空間は, その利用時間に 応じて，使用料金を課金するものである。

(1)ファシリティコストを入居部門が獲得した収 益に対応した費用として配分すること

(2)入居部門に対してファシリティコストの削減 を常に認識してもらうこと

なお，その場合の課金料金の設定方法は, ファ シリティコストを入居面積で按分する方法, 周辺 の類似したファシリティの賃料相場に基づく方法, 及び，両者を折東した方法等があるが，入居する 全ての部署に公平なものとする必要がある。
(5) ワークプレイスづくり

ワークプレイスとは, 働く人 (People) が生産 性を発揮できる仕事の仕方 (Process) にふさわし い仕事の場（Place）のことであり, ワークプレイ

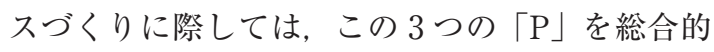
に調整して, 経営目的の達成するためにべストプ ラクティスを追及する。

(1)財務の視点からは, 組織変更の大きさを示す 指標であるチャーンレート（Churn Rate）が 高い組織では, 組織変更や人事異動の際は人 と書類のみ移動して, レイアウト変更を行わ ないユニバーサルプラン等が採用される。

(2)供給の視点からは, 外出が多い営業部門等を 中心として, 特定の個人専用の机を設けない ノンテリトリアル・オフィス（フリーアドレ ス，ホテリング等）のワークプレイスを採用 する等, 常時, 空き机が最小となることを目 標にスペース効率が追求される。

(3)品質の視点からは, 「知的生産性の向上」と 「働く人の多様化」及び「働き方の多様化」へ の対応等が重要なテーマとなる。

ワークプレイスを構成する最小単位をワークス テーションといい,「個人レベルの業務に必要な最 小限の機能を組み合わせた作業設備の基本単位」 と定義されている。ワークプレイスで遂行される 業務は, 例えば, 個人で集中して遂行すべき業務, グループで頻繁に情報交換をしながら遂行すべき 業務等, 多種多様であり, これらに適したワーク ステーションとオフィスレイアウトを採用する必 要がある。

近年では, 空き机を減らしてスペース効率を追 求するのを目的とするのではなく，このような多 種多様な業務特性とその変化に対応することを目 的として，ノンテリトリアル・オフィスが採用さ れることもある。

「知的生産性の向上」の観点からは, 2007年に経 済産業省が策定した「感性価值創造イニシアティ 


\begin{tabular}{|c|c|c|c|}
\hline+ & \multicolumn{2}{|c|}{ 暗默 知 } & + \\
\hline \multirow{3}{*}{$\begin{array}{c}\uparrow \\
\text { 暗 }\end{array}$} & Socialization & Externalization & \multirow{3}{*}{$\begin{array}{l}\downarrow \\
\text { 形 } \\
\text { + }\end{array}$} \\
\hline & 一共有化一 & 一表出化一 & \\
\hline & 刺激し合う & アイデアを表に出す & \\
\hline $\begin{array}{l}\text { 黙 } \\
\text { 知 }\end{array}$ & Internalization & Combination & $\begin{array}{l}\text { 式 } \\
\text { 知 }\end{array}$ \\
\hline \multirow{2}{*}{$\uparrow$} & 一内面化一 & 一連結化一 & \\
\hline & 自分のものにする & まとめる & \\
\hline+ & $\leftarrow$ & 知 & + \\
\hline
\end{tabular}

図 4：SECIモデル 5 )

ブ」の一貫で推進されている「クリエイティブ • オフィス推進運動」が注目されている。具体的に は，例えば，ナレッジマネジメントの基礎理論で, 知識移転のプロセスである「SECIモデル」（図 4 参照）に基づいたワークプレイスづくりも行われ ている。また，「働く人の多様化」の観点からは， 少子高齢化社会を迎え, 高齢者や障害を持つ人, 女性，外国人等，さまざまな人の出社から退社ま での一連の行動に配慮したユニバーサルデザイン が欠かせなくなっている。更に,「働き方の多様化」 も進展に伴い, 従来のセントラルオフィスに加え て, SOHO (Small Office Home Office), サテラ イトオフィス, ビジネスセンター, ドロップイン オフィス等,「いつでもどこでも」働ける環境が整 備されてきている。

\section{5 . 運営維持}

(1) 長寿命化

施設を継続的に適切な状態に保って，その機能 と性能を発揮させるためには, 的確な維持保全を 実施していかなければならない。

その際は, 時間と共に進行する経年劣化と陳腐 化を常に認識しつつ，その寿命を全うするまでの ライフサイクルを考慮したマネジメント（図 5 参 照）を行うことが肝要である。また，自然災害や 不正侵入及び設備故障, 物の落下や人の転落等に

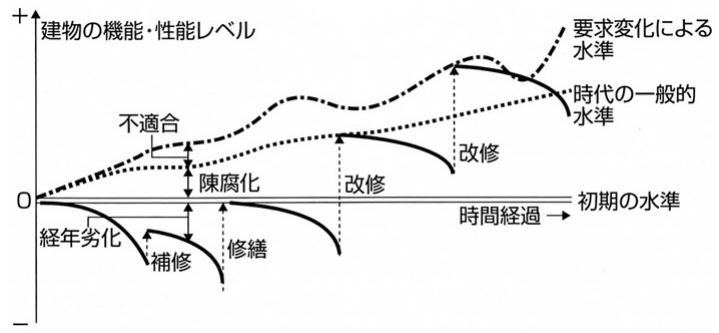

図 5：劣化と修繕・改修との関係 ${ }^{2)}$

表 4：日常的な運営維持 2

\begin{tabular}{|c|c|c|}
\hline \multirow[b]{2}{*}{ 維持保全 } & 保 & 点検、保守、修䋨、改修等 \\
\hline & 維持管理 & $\begin{array}{l}\text { 熱·空気、照明、音·振動、給 } \\
\text { 排水衛生、清掃、病害虫防除、 } \\
\text { 廃棄物、植栽等 }\end{array}$ \\
\hline \multirow[t]{2}{*}{ 運営管理 } & 共 用 部 & $\begin{array}{l}\text { 設備運転·監視、鍵管理、保 } \\
\text { 安·防災管理、環境管理、駐 } \\
\text { 車場管理、施設資産管理、賃 } \\
\text { 貸借管理等 }\end{array}$ \\
\hline & 専 用 部 & $\begin{array}{l}\text { スペース管理、レイアウト変 } \\
\text { 更管理等 }\end{array}$ \\
\hline \multirow{2}{*}{ サービス } & 業務支援 & $\begin{array}{l}\text { 受付、応接、会議、メール等 } \\
\text { に関わるサービス }\end{array}$ \\
\hline & 生活支援 & $\begin{array}{l}\text { 食堂、自動販売機、健康管理 } \\
\text { 設備を介したサービス }\end{array}$ \\
\hline
\end{tabular}

よる公衆災害等のリスクに着目して, 予防保全と 事後保全を使い分ける等, 優先順位をつけて計画 的な維持保全を実施することが重要である。

(2) 経費削減

日常的に実施されている運営維持は, 表 4 に示 す通りである。

これらの業務は, その運営のみを外注されるこ とが多いが，その運営だけでなく設計や計画も含 めたアウトソーソングが行われることもある。そ 
の際は, 仕様発注ではなく, SLA/KPI（Service Level Agreement/Key Performance Indicator)に よる性能発注が行われる例も増えている。具体的 には, SLAにより, 受注者と発注者の間で発注す る業務の要求水準に関する合意をした上で契約を 締結して，KPIにより，受注者の業績評定を行う もので, SLA/KPIが適切に行われた場合は, 発注 者は経費削減, 受注者は利益確保が実現する。

適切な性能発注を行うためには, 日常的に施設 の利用者とのコミュニケーションを図り，常に利 用者の要求と満足度を把握しておくことが重要で ある。例えば，施設に関わるコールセンターで利 用者からの苦情や要求をワンストップで受け付け て対処し, その後, 利用者にその対処の良否を記 入したレスポンスカードを提出して貫う仕組み等 が有効である。

なお，数多くの施設を所有している場合は，複 数の施設に関わる運営維持業務を一括して発注す ることにより，経費削減を図ることも可能である。 (3) 環境保全

昨今では，環境に配慮した施設の資産価値が高 く評価される時代となっている。

2009年12月に開催されるコペンハーゲン会議 （COP15）において, 日本の温室効果ガスの削減 目標を 2005 年比で $\triangle 15 \%$ とされる見通しである。 2006年度においては，日本の温室効果ガスの約 $17 \%$ は，「業務その他部門」から排出されており， オフィスビルにおけるエネルギー消費量の削減は, 地球温暖化防止に直結する。また，2009年 4 月に は省エネルギー法が改正されると共に, 東京都に おいても大規模事業所への「温室効果ガス排出総 量規制義務と排出量取引制度」が策定された。更 に, 欧米各国を中心に「建物環境評価指標」が普 及しているが，日本においても2002年にCASBEE が開発されてその活用が拡大している。

このような状況から, 室内環境の快適性を確保 しつつ, 環境負荷を削減する取り組みの重要性が
増大している。日常的には, 例えば, 設備のエネ ルギー管理を行うシステムであるBEMS（Building and Energy Management System) から得ら れたデータの活用等による省エネルギー推進等が 行われている。

\section{N． FMを規定する情報の現状と課題}

\section{1．内部情報}

（1）収集管理の体制

FMに必要な自組織内の情報は, 表 5 の通り, 「経営に関する情報」と「施設に関する情報」に分 類できる。その中で, 特に重要なのは, 施設毎の スペースとコスト及び人員に関する情報である。

これらの情報を収集するためには，まず，有形 固定資産である施設の棚卸しを行い，次に，次の 事項を明確にする等により，これらの情報を最新 の状態に維持する体制を構築する必要がある。

(1)情報の種類と所在

(2)情報を集約するルール

(3)情報の利用と管理の方法

表 5：FMを規定する内部情報 ${ }^{2)}$

\begin{tabular}{|c|c|c|}
\hline \multirow{4}{*}{$\begin{array}{l}\text { 経 } \\
\text { 営 }\end{array}$} & 概 要 & 定款、経営方針、財務諸表等 \\
\hline & 資産 & 取得価格、時価、償却状況等 \\
\hline & 組織 & 組織図、部署、人員、座席配置等 \\
\hline & 文化 & 組織体のもつ理念、習慣、風土等 \\
\hline \multirow{9}{*}{$\begin{array}{l}\text { 施 } \\
\text { 設 }\end{array}$} & 概 要 & 竣工日、用途、床荷重、設備容量等 \\
\hline & スペース & 所有形態、各種面積、利用実態等 \\
\hline & コスト & ファシリティコスト \\
\hline & 調査結果 & 利用者満足度、劣化度、利用度等 \\
\hline & 家具什器 & 什器、備品、事務用機器等 \\
\hline & 運営維持 & 故障、保守、点検、修繥の履歴等 \\
\hline & 設計図書 & 新築と修繕·改修の時点の設計図書 \\
\hline & 契約図書 & 不動産契約、工事契約、委託契約等 \\
\hline & 登記書類 & 不動産登記等 \\
\hline
\end{tabular}




\section{(4)ITツールの活用方法}

(2) 収集管理の留意点

FMに必要な自組織内の情報は, ファシリティ を利用する組織のほか, 総務, 財務, 経理, 管財 等, 多くの部署から定期的に最新情報を提供して もらうことが必要不可欠であるが，そのためには， 次の 2 点に留意する必要がある。

(1)各部署の通常業務の循環の中で無理なくFM 情報を提供して貴うこと

(2)経営と各部署の業務に役に立つFMの成果を 出し続けること

これらの情報の収集管理には, ITツールを有 効に活用する必要がある。その際は, デー夕の二 重入力を避けるという観点からも，既存の情報処 理システムと連携するのが有効である。例えば, 統合基幹業務システムと呼ばれるERP (Enterprise Resource Planning) 等との連携や, 管理会計の観点から, 既存の財務会計システムか ら, ファシリティコストのデータを抽出する等が 有効である。

また，FMに関わる情報システムは，情報を提 供する者と情報を活用する者が多種多様であるこ とから, インターネットを介して, いつでもどこ からでもアクセスができるASP (Application Service Provider）を活用することも有効である。

\section{2. 外部情報}

FMに必要な自組織外の情報は, 表 6 の通りで あるが, 特に重要なのは, 日進月歩で進化する

表 6 ：表 FMを規定する外部情報 ${ }^{2)}$

\begin{tabular}{l|l}
\hline 不 動 産 & 公示価格、周辺類似施設の価格と賃料等 \\
\hline 建 設・設 計 & 建設物価、建築技術に関する最新情報等 \\
\hline 外部専閒家 & 設計者、コンサルタント等に関わる情報 \\
\hline 関 連 法 規 & ファシリティに関わる関連法規の情報 \\
\hline 運 営 維 持 & 運営維持に関わる最新情報 \\
\hline $\mathrm{F} \mathrm{M}$ 関 連 & $\mathrm{FM}$ に関する各種手法等に関する情報 \\
\hline
\end{tabular}

$\lceil F M$ 関連の情報」と「不動産関連の情報」である。 近年では, ビジネスを取り巻く環境の変化が激 しく, 組織変更や人員の増減も頻繁に行われ, こ れに対応してファシリティの規模や使い方につい ても変化が求められる。このような変化に俊敏に 対応するためには，内部情報のみならず外部情報 も常に収集管理しておく必要がある。

\section{3 . 現状の課題}

FMの推進に際しては, 全てのファシリティを 一元的にマネジメントする体制を整えることが重 要であるが,このような体制を整備して，これを 維持していくことが最も大きな課題である。

具体的には, 内部情報の収集管理する体制, 即 ち，ファシリティの全てを棚卸しして，その情報 を常に最新な状態に維持する体制の構築, 特に, 日常的に各部署から発生するファシリティコスト を集約する仕組みの構築とその維持である。

また，外部情報については，自組織で使用して いるあるいは使用しょうとしている施設周辺の不 動産の価格や賃料及びその動向に関する情報を入 手して，自組織で使用している施設の時価を簡易 に評価できる仕組みの整備が望まれる。

\section{V． 不動産価格や景気とFMとの関係}

JFMAは, 約 200 社の法人会員と約 1,000 名の個 人会員で構成されているが, 社団法人となった 1997年以降，毎年，JFMA FORUM（FM国際大 会）を開催すると共に, 常時, ウィークリーセミ ナー等を開催しており, その中で数多くのFM事 例が発表されている。

筆者の主観によるところも大きいが, 図 6 の「東 京区部における平均空室率の推移」を参照しなが ら, これらのFM事例を概観してみると, 不動産 価格や景気がFMに与える影響については, 次の 通り，整理することができる。

(1)「FM統括マネジメント」と「FM評価」に関 する発表は, 徐々に増加しているが, これは, 


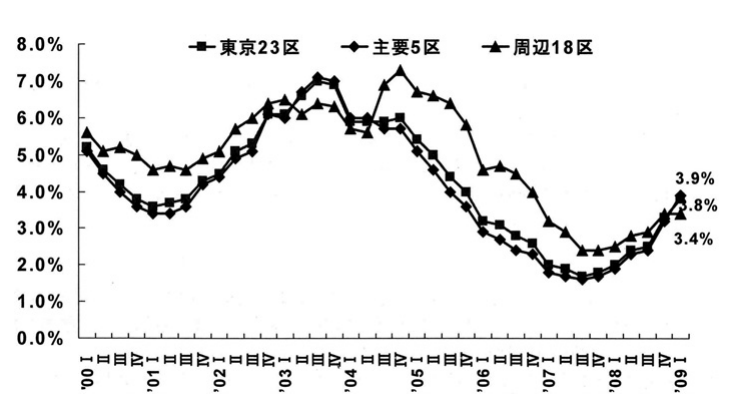

図 6：東京区部における平均空室率推移 6) (出典：シービー・リチャードエリス総合研究所(株)調べ)

長期にわたる景気停滞により，有形固定資産 の総量適正化とその最大利活用の重要性が認 識されてきたことに起因していると思われる。 (2)特に, 近年では, 地方自治体から (1)と同様の 発表が急増しているが, これは, 財政健全化 法の施行と公会計の改革が起因していると思 われる。

(3)2003年をピークとした大規模なオフィスビル の供給により, 地価の高い都心を避けて, 郊 外にオフィスを展開していた企業の都心回帰 が始まった。これらの事例は, 基本的には賃 借であるが, 近年では, 大規模なテナントビ ル仕様のオフィスビルを建設して, 自らがそ のビルに入居する例も多い。この現象にも， 地価と賃料及び景気が密接に影響していると 推測される。

(4)都心では, スペース効率の向上, 働き方の多 様化への対応, 知的生産性の向上等, 複数の 目的を設定したノンテリトリアル・オフィス
やコミュニケーション重視の大規模なワーク プレイスの事例が増加している。これは, 高 額な地価や顀料も一因していると思われる。

(5)郊外では, 高度なITインフラストラクチャの 整備を背景として, 働き方の多様化への対応, 知的生産性の向上を目的として, 生活支援施 設の充実させた新たなワークプレイスを構築 した事例も数多い。これは, 施設の保有費の 削減, 通勤時間と交通費の削減等も狙ったも のと推測される。

(6「運営維持」に関する発表, 特に,「維持保全」 と「運営管理」に関する発表は, 常に, 多く の事例が発表されている。これは, 長期にわ たる景気停滞による費用削減のニーズが高い こと, 約40年前のいざなぎ景気の頃に建設さ れた多くの建物の老朽化が起因していると思 われる。

\section{V. おわりに}

FMは, 経営資源の「もの」に着目した経営管 理活動であるが，「環境」と「もの」を大切に利用 することが求められている今日では，官民を問わ ず多くの組織で実践されており, その対象は, オ フィスに限らず工場や学校や病院及びホテル等多 岐に亘っている。

FMは, 前述の通り, 景気や不動産の価格及び 評価とも密接な関係があることから, 今後, 不動 産学的な観点からFMに関する調査や研究が進む こと望まれる。

6)(社)日本サステナブル・ビルディング・コンソーシアム (2009.07)，「CASBEE不動産評価活用マニュアル (暫定版)」 